\title{
GROWTH OF Bauhinia forficata Link, Curcuma zedoaria Roscoe AND Phaseolus vulgaris L. CELL SUSPENSION CULTURES WITH CARBON SOURCES
}

\author{
Marcia Ometto Mello ; Carlos Tadeu Santos Dias ${ }^{2}$; Antônio Francisco Campos Amaral'; \\ Murilo Melo ${ }^{\text {* }}$ \\ ${ }^{1}$ Depto. de Ciências Biológicas/CEBTEC - USP/ESALQ, C.P. 9 - CEP: 13418-900 - Piracicaba, SP. \\ ${ }^{2}$ Depto. de Ciências Exatas - USP/ESALQ \\ *Corresponding author<mmelo@carpa.ciagri.usp.br>
}

\begin{abstract}
Cell suspension cultures of Bauhinia forficata Link, Curcuma zedoaria Roscoe and Phaseolus vulgaris L. were used to test plant ability to utilize an alternative to sucrose as carbon source and energy for growth. Glycerol, sorbitol and galactose were the alternative carbon sources tested. Cell suspension cultures established on liquid medium containing sucrose were transferred to culture medium supplemented with sucrose or glycerol, or sorbitol, or galactose as the sole carbon source. Fresh and dry weight increasing and protein content showed marked differences among the different carbon sources used. Sucrose was the best carbon source for all the three plant species tested. Galactose and glycerol promoted slow or no growth of the three studied species. Sucrose in liquid medium promoted initiation of meristemoid formation. Sorbitol, which was ineffective on promoting significant growth, was the only alternative carbon source tested that also promoted this effect.

Key words: sucrose, glycerol, sorbitol, galactose, tissue culture

\section{CRESCIMENTO DE CULTURA DE CÉLULAS EM SUSPENSÃO DE Bauhinia forficata Link, Curcuma zedoaria Roscoe E Phaseolus vulgaris L. EM FONTES DE CARBONO}

\begin{abstract}
RESUMO: Culturas de células em suspensão de Bauhinia forficata Link, Curcuma zedoaria Roscoe e Phaseolus vulgaris $\mathrm{L}$. foram usadas para avaliar a eficiência de fontes alternativas de carbono e energia. Glicerol, sorbitol e galactose foram as fontes alternativas estudadas. As culturas de células estabelecidas em meio líquido contendo sacarose foram transferidas para meios de cultura suplementados com sacarose ou glicerol ou sorbitol ou galactose. A fonte de carbono afetou distintamente os ganhos de matéria fresca, matéria seca e o acúmulo de proteína. A sacarose foi a melhor fonte de carbono para as três espécies estudadas. Galactose e glicerol promoveram pequeno crescimento das três espécies estudadas. A sacarose utilizada como fonte de carbono no meio líquido, promoveu o início de organização celular conhecido como a formação de meristemóides. Sorbitol, que não promoveu crescimento significativo, foi a única fonte alternativa de carbono testada que também promoveu este efeito.
\end{abstract}

Palavras-chave: sacarose, glicerol, sorbitol, galactose, cultura de tecido

\section{INTRODUCTION}

Many factors affecting the growth of excised plant organs, tissues and cells in vitro have been studied extensively over the last 30 years, including plant growth regulators, light, temperature, medium $\mathrm{pH}$, humidity, gas exchange and the presence of harmful microorganisms (Leifert et al., 1995). On the other hand, plant carbohydrate requirements in vitro have rarely been studied in detail and still are poorly understood (Leifert et al., 1995; Swedlund \& Locy, 1993).

Sucrose is the most commonly used carbohydrate in plant tissue or cell culture (Vu et al., 1993). This is due to the widespread role of this particular disaccharide as a transport molecule, thanks to its high solubility in water, its electrical neutrality, its apparent lack of inhibitory effect on the majority of biochemical processes, and its non-reducing character which makes it less likely than other sugar, such as glucose or fructose, to interact with some of other functional groups that occur in plants (Smith, 1995). The majority of in vitro studies have concluded that sucrose supports near optimal rates of growth and it is relatively inexpensive (Swedlund \& Locy, 1993). In spite of the widespread use of sucrose, other sugars have also been reported as being suitable carbon sources for different plant species (Spiegel-Roy \& Saad, 1997; Jain et al., 1997). A number of carbohydrates besides sucrose are translocated in plants (Loescher, 1987), and furthermore have been reported to be part of cellular components or related to cell differentiation. The occurrence of these carbohydrates varies from genus to genus and even from species to species to the extent that they can be useful for taxonomic classification purposes (Swedlund \& Locy, 1993). It has also been well documented that certain plant tissues may contain and/or utilize different carbohydrates at the same time. It is then 
not surprising that carbon sources other than sucrose might be effective in promoting in vitro tissue specific growth responses in a given species (Swedlund \& Locy, 1993). Furthermore, several reports have pointed out these carbon sources as inducers of cell differentiation in some plant species (Lemos \& Blake, 1996; Karhu, 1997; Bellettre et al., 1999). Galactose, glycerol and sorbitol are examples of alternative carbon sources that have been tested in vitro for different purposes in a wide range of plant species.

Regeneration of $B$. forficata plants from cells has been obtained by organogenesis and embryogenesis in our lab (Carvalho, 1998) in culture medium containing sucrose, but this process has given poor conversion. Most of somatic embryos and meristemoids fail to form plants. This has also been true for $P$. vulgaris. Since regeneration of plants by organogenesis or somatic embryogenesis from cells or callus cultures has not been easily obtained for most of Fabaceae species, new alternatives of culture, like different carbon sources, should be evaluated.

According to Jones \& Veliky (1980), changes in carbon source could provide the yield of more diverse products by activation of alternate metabolic routes via the change of carbon flux, therefore being an excellent tool to study plant cell metabolism, besides providing precursors needed for certain plant species to trigger cell differentiation. The present paper aims to evaluate the effects of sucrose, galactose, glycerol and sorbitol on growth and protein accumulation of cell suspension cultures of Bauhinia forficata, Curcuma zedoaria and Phaseolus vulgaris in vitro, as a support to investigate the effect of these sugars on promoting cell differentiation in these plant species.

\section{MATERIAL AND METHODS}

\section{Callus formation}

Hypocotil segments $(1 \mathrm{~cm})$ of in vitro germinated Bauhinia forficata Link plants were inoculated on half strength MS (Murashige \& Skoog, 1962) culture medium supplemented with $30 \mathrm{~g} \mathrm{~L}^{-1}$ sucrose and $17.7 \mu \mathrm{M}$ BAP for callus induction.

Calli of Curcuma zedoaria Roscoe were obtained by inoculating root segments of in vitro micropropagated Curcuma zedoaria Roscoe plants. Segments were inoculated on MS culture medium supplemented with $30 \mathrm{~g} \mathrm{~L}^{-1}$ sucrose, $13.4 \mu \mathrm{M}$ NAA and 2.2 $\mu \mathrm{M}$ BAP.

Calli of Phaseolus vulgaris were obtained by inoculating embryos, after appropriate sterilization procedure, on MS culture medium supplemented with $30 \mathrm{~g} \mathrm{~L}^{-1}$ sucrose and $22.6 \mathrm{mM}$ 2,4-D.

All media were solidified with $2.3 \mathrm{~g} \mathrm{~L}^{-1}$ Phytagel (Sigma) and adjusted to $\mathrm{pH} 5.8$ with $0.1 \mathrm{M} \mathrm{KOH}$ before autoclaving at $120^{\circ} \mathrm{C}$ for 30 minutes. Cultures were maintained at $25 \pm 2^{\circ} \mathrm{C}$ under a 16 -hour photoperiod $\left(50.8 \pm 6.6 \mu \mathrm{mol} \mathrm{m} \mathrm{m}^{-2} \mathrm{~s}^{-1}\right)$ by using cool-white fluorescent lamps, General Electric/40W (B. forficata and P. vulgaris) or under darkness $(C$. zedoaria). Calli subculturing were carried out at every 30 days.

\section{Initiation of cell suspension cultures}

Cell suspension cultures for all three plant species were initiated from calli by culturing fragmented callus $(5 \mathrm{~g})$ in $250 \mathrm{~mL}$ Erlenmeyer flasks containing 100 $\mathrm{mL}$ of liquid callus inducing medium under agitation on rotatory shaker at 60 cycles/minute, under the same physical conditions as described for callus cultures. Subcultures were carried out at a 3-week interval.

\section{Growth on different carbon sources}

From the resulting cell suspensions $0.5 \mathrm{~g}$ of cells was transferred to $125 \mathrm{~mL}$ Erlenmeyer flasks containing $10 \mathrm{~mL}$ of the same composition culture medium containing varied carbon sources: sucrose $\left(30 \mathrm{~g} \mathrm{~L}^{-1}\right)$, as the standard carbon source, or galactose $\left(60 \mathrm{~g} \mathrm{~L}^{-1}\right)$ or sorbitol $\left(60 \mathrm{~g} \mathrm{~L}^{-1}\right)$ or glycerol $\left(120 \mathrm{~g} \mathrm{~L}^{-1}\right)$, as alternative carbon sources. The amount of each alternative carbon source was calculated to provide the same carbon concentration as the one provided by $30 \mathrm{~g} \mathrm{~L}^{-1}$ of sucrose. The cultures were maintained under the same physical conditions as previously described for cell suspension culture initiation. Four flasks of each treatment were periodically taken (every 5 days) from the first day to day $45^{\text {th }}$.

\section{Fresh and dry mass determination}

Cell suspension cultures from $125 \mathrm{~mL}$ Erlenmeyer flasks were vacuum filtered through number 1 Whatman paper and transferred to a tared aluminum can. After the determination of fresh mass, cells were lyophilized at $-50^{\circ} \mathrm{C}$ for 24 hours in a Freeze Dryer 4.5 (Labcon) and weighed.

\section{Soluble protein concentration}

Lyophilized cells were handily homogenized using a pistil and mortar in liquid nitrogen in presence of cold $200 \mathrm{mM}, \mathrm{pH} 7.8 \mathrm{HEPES} / \mathrm{KOH}$, containing $3 \mathrm{mM}$ EDTANa $2 \cdot 2 \mathrm{H}_{2} \mathrm{O}, 3 \mathrm{mM}$ magnesium acetate, $10 \mathrm{mM}$ dithiothreitol (DTT) and 1\% (w/v) polyvinyl-pyrrolidone (PVP) buffer and centrifuged $(10,000 \mathrm{xg})$ for 20 minutes at $4^{\circ} \mathrm{C}$ to separate the soluble fraction used as protein source. The supernatant was sampled in duplicate to estimate protein content (Bradford, 1976).

\section{Statistical Analysis}

The experiments consisted in 12 treatments ( 3 plant species and 4 carbon sources) distributed into four randomized blocks (repetitions) in factorial design. A regression analysis was tested using polynomial models, and the best model was chosen based on the maximun $R^{2}$ (the coefficient of determination) significative value. The analysis was based on the means of the treatment values on each sampling time by the Excel and the Statistical Analysis System (SAS, 1996). Analysis of variance was also carried out.

\section{RESULTS AND DISCUSSION}

The results for the effect of alternative carbon sources on cell suspension cultures of Bauhinia forficata 
Link, Curcuma zedoaria Roscoe and Phaseolus vulgaris L. are shown in Figure 1 (fresh mass), Figure 2 (dry mass) and Figure 3 (protein content).

The utilization pattern of sucrose, galactose, glycerol and sorbitol, based on the final cell yield after 45 days of growth, were different for all three cultures indicating that growth was strongly influenced by carbon source.

Confirming that sucrose is the most commonly used carbohydrate for plant tissue and cell culture $(\mathrm{Vu}$ et al., 1993), it promoted the best results for cell growth and protein accumulation for all the three studied species. It is assumed that sucrose is the preferred carbohydrate for in vitro culture because it is the main transported form of carbohydrate in most plant species, including those used in this study (Zimmermann \& Ziegler, 1975). C. zedoaria and $P$. vulgaris cell cultures in the presence of

\section{Curcuma zedoaria Roscoe}

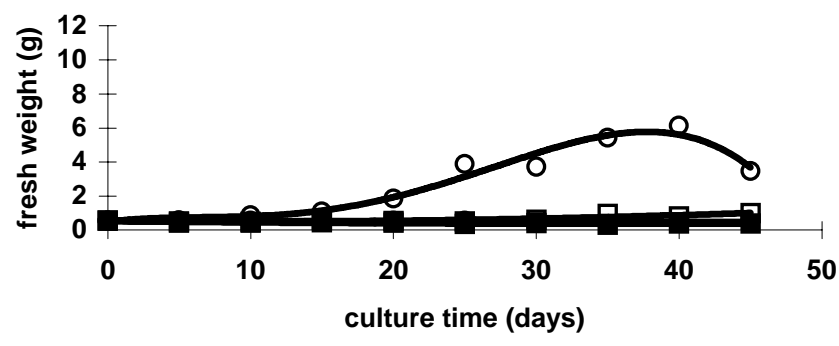

Bauhinia forficata Link

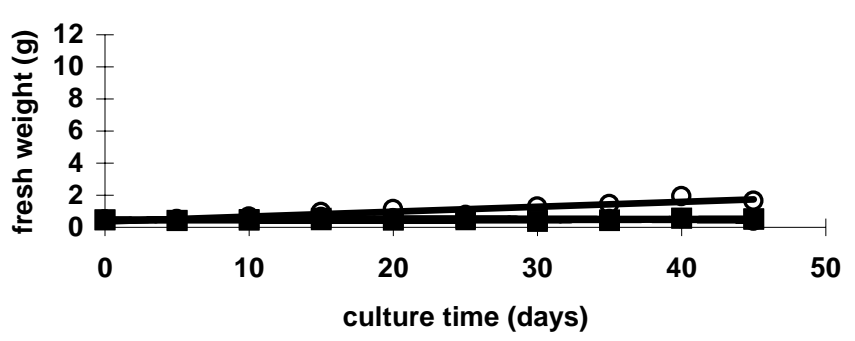

Phaseolus vulgaris

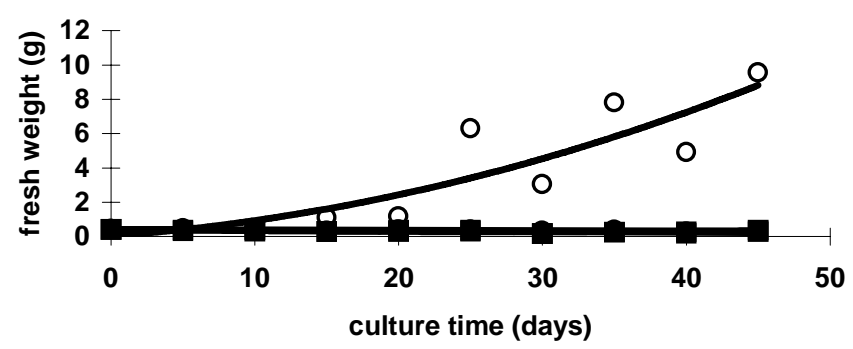

Figure 1 - Fresh weight matter accumulation by $C$. zedoaria Roscoe (A) (C.V.\%=8.21), B. forficata (B) $($ C.V. $\%=5.46)$ and $P$. vulgaris (C) $($ C.V.\% $=9.31)$ cell suspension cultures, respectively, supplemented with sucrose (o) $\left(R^{2}=0.96\right.$; $\left.\mathrm{R}^{2}=0.86 ; \mathrm{R}^{2}=0.78\right)$, sorbtiol $(\bullet)\left(\mathrm{R}^{2}=0.27 ; \mathrm{R}^{2}=0.28\right.$; $\left.R^{2}=0.50\right)$, galactose $(\square)\left(R^{2}=0.83 ; R^{2}=0.33 ; R^{2}=0.51\right)$ and glycerol $(\boldsymbol{\square})\left(\mathrm{R}^{2}=0.74 ; \mathrm{R}^{2}=0.40 ; \mathrm{R}^{2}=0.53\right)$. sucrose showed a typical growth curve based on dry matter, including a lag phase of approximately 10 days, when the cells were still adapting to the new medium, followed by a log phase from the day $10^{\text {th }}$ to day $25^{\text {th }}$, with intensive growth and ending with the stabilization of growth from the day $25^{\text {th }}$ to day $35^{\text {th }}$ and a decrease in dry matter after 35 days of culture. This could have been probably caused by the exhaustion of sucrose in the culture medium or accumulation of toxic substances in the medium (Figures $2 \mathrm{~A}$ and $2 \mathrm{C}$ ). On the other hand, $B$. forficata cell cultures did not show this typical curve for fresh and dry weights, but an almost straight line characterized by the first degree regression equation (Figure 2B). This may be explained by the slow growth of this cells species that could be an in vitro characteristic of woody legumes.

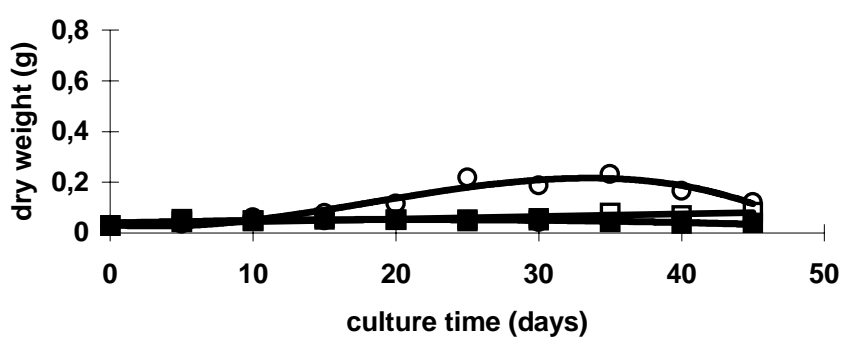

Bauhinia forficata Link

B

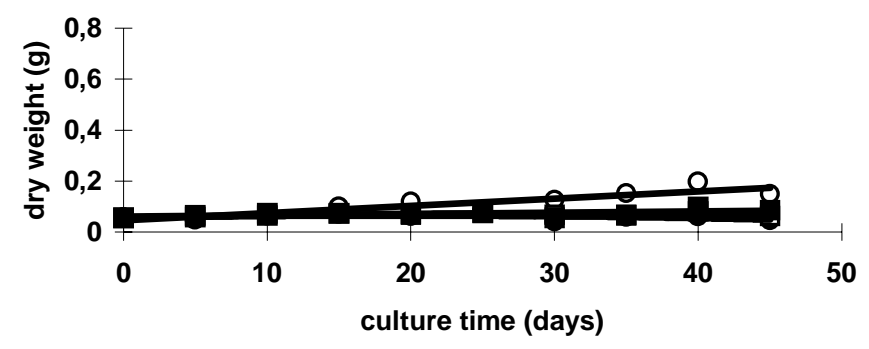

Phaseolus vulgaris

C

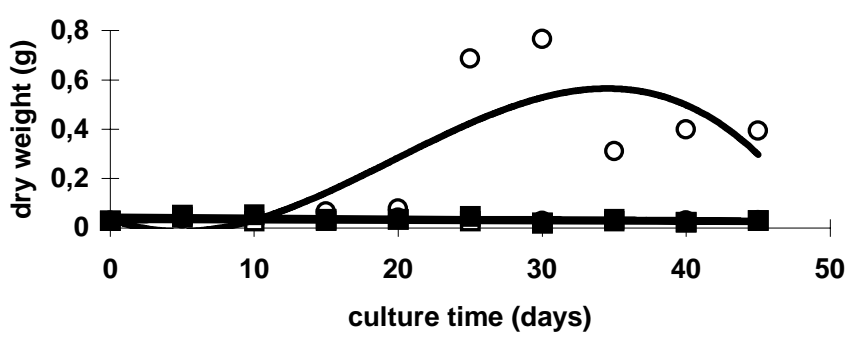

Figure 2 - Dry weight matter accumulation by C. zedoaria Roscoe (A) (C.V.\%=11.43), B. forficata (B) $($ C.V. $\%=8.56)$ and $P$. vulgaris $(C)(C . V . \%=13.79)$ cell suspension cultures, respectively, supplemented with sucrose (o) $\left(R^{2}=0.93\right.$; $\left.R^{2}=0.82 ; R^{2}=0.63\right)$, sorbtiol $(\bullet)\left(R^{2}=0.40 ; R^{2}=0.27\right.$; $\left.{ }^{2}=0.35\right)$, galactose $(\square)\left(R^{2}=0.88 ; R^{2}=0.59 ; R^{2}=0.23\right)$ and glycerol $(\square)\left(R^{2}=0.53 ; R^{2}=0.34 ; R^{2}=0.25\right)$. 
Even though galactose and glycerol have proven to be effective carbon sources for induction of somatic embryogenesis in vitro of Lemna minor (Frick \& Morley, 1995), Cichorium (Bellettre et al.,1999), Annona muricata (Lemos \& Blake, 1996) and Citrus (Cabasson et al., 1995; Spiegel-Roy \& Saad, 1997), they supported only slow or no growth of $B$. forficata, $C$. zedoaria and $P$. vulgaris cells (Figures 1 and 2).

The variable obtained results on the effect of these carbon sources are probably due to differences in the sensitivity of plant species to these carbohydrates or to the products generated during their metabolism. In addition to that, we can infer that the existing metabolic pathways for utilization of galactose and glycerol, as a sole carbon source, may not maintain adequate production levels of intracellular precursor carbon chain and energy since an adequate level of gluconeogenic enzymes is needed.

Curcuma zedoaria Roscoe

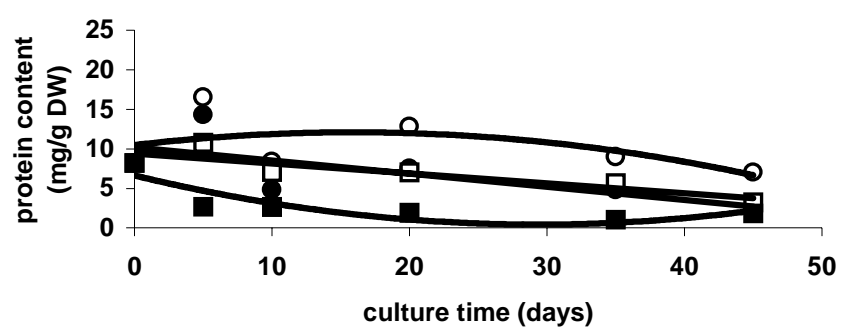

Bauhinia forficata Link

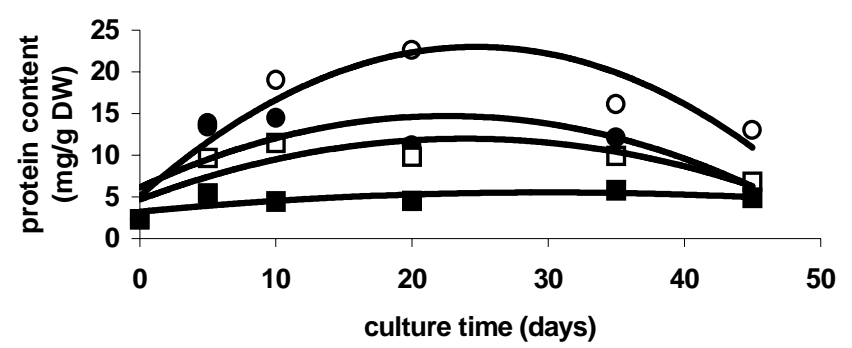

Phaseolus vulgaris

C

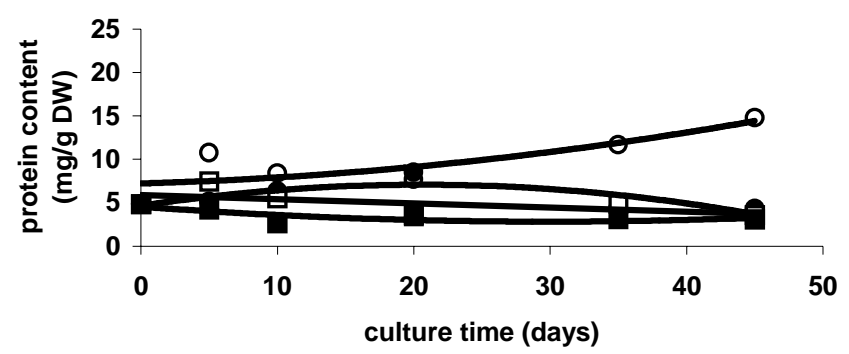

Figure 3 - Soluble protein accumulation by C. zedoaria Roscoe (A) (C.V.\%=19.15), B. forficata (B) (C.V.\%=11.22) and P. vulgaris (C) (C.V.\%=13.34) cell suspension cultures, respectively, supplemented with sucrose (o) $\left(R^{2}=0.31\right.$; $\left.R^{2}=0.85 ; R^{2}=0.69\right)$, sorbtiol $(\bullet)\left(R^{2}=0.50 ; R^{2}=0.54\right.$; $\left.R^{2}=0.60\right)$, galactose $(\square)\left(R^{2}=0.77 ; R^{2}=0.66 ; R^{2}=0.35\right)$ and glycerol $(\square)\left(R^{2}=0.77 ; R^{2}=0.50 ; R^{2}=0.60\right)$.
According to Cabasson et al. (1995), galactose could have a negative effect on growth since it inhibits synthesis of UDP-glucose, an intermediate required for the cell wall synthesis. Addition of this carbohydrate to the culture medium has been reported to show a toxic effect on some species such as Albizzia julibrissin (El Maataoui et al., 1998).

Sorbitol was unable to support cell growth of all the three cultures (Figures 1 and 2). These negative results suggest that sorbitol is not efficiently metabolized by cell cultures of the three species studied corroborating the finding that it is not present in the sieve-tube exudates of any of these species (Zimmermann \& Ziegler, 1975). The inability of cell cultures to utilize sorbitol could be due either to its reduced uptake or the absence of sufficient sorbitol dehydrogenase activity in these species (Jain et al, 1997). On the other hand, sorbitol has been successfully used on in vitro cultures enhancing the micropropagation rate of Prunus mume (Harada \& Murai, 1996), the organogenesis of Malus domestica (Karhu, 1997) and the somatic embryogenesis of Lilium species (Okazaki et al., 1995) and Oryza sativa (Jain et al., 1997). It has also been reported to be one of the principal photosynthetic products in leaves of members of Rosaceae, Prunoideae and Spiroideae families what make us believe in the occurrence of specific enzymes involved in sorbitol oxidation to other sugars which are used by the cells as source of energy and carbon chain precursors (Marino et al., 1993).

In our study, sorbitol also promoted the initiation of cellular organization in all the three studied species. After 10 days of culture, cell differentiation was observed in the cell suspension cultures supplemented with sucrose and sorbitol. At this time, cell division led to the formation of cell clusters characterized by their green color and small cytoplasmicaely dense cells. These structures identified as meristemoids (data not shown) are expected to develop to meristems and then to shoot apex. Culture medium containing sorbitol promoted faster cellular organization than those suplemented with sucrose (data not shown). According to Tsukahara et al. (1996), higher concentration of sorbitol $\left(60 \mathrm{~g} \mathrm{~L}^{-1}\right)$ stimulated regeneration of Oryza sativa plantlets since osmotic potencial of the utilized medium is an important factor for this process. Osmotic stress may disrupt the plasmodesmatal connections between the preembryogenic cells, thus making the cells physiologically isolated and allowing a high number of cells to differentiate contributing also to the somatic embryogenesis process (Jain et al., 1997). In our point of view, the cell differentiation could be even higher since conditions were not optimized, evaluations were not carefully carried out and the experiment aimed at cell growth and not cell differentiation. Auxin was maintained in the liquid culture medium, therefore blocking cell differentiation. This finding confirms the literature reports of the effect of sorbitol on cell differentiation, therefore 
suggesting a morphogenic function of this sugar. The negative results for the use of alternative carbon sources may not be attributed to osmotic effect since it seems that water content of the calli did not change much during the culture growth. This phenomenon can be visualized comparing the obtained curves for fresh and dry weight matter accumulation.

The highest protein accumulation was also achieved by the addition of sucrose in the culture media (Figure 3). Observed increases with other carbon sources are probably due to the mobilization of reducing sugars, sucrose and starch reserves (Frick, 1994) to protein synthesis, since dry weight did not change much when alternative carbon sources were used as supply. Sorbitol promoted the highest protein accumulation level when compared to the two other alternative carbon sources. It is known that a high concentration of some proteins in the callus tissue of in vitro cultivated species is a remarkable characteristic of tissues induced to differentiate (Burns \& Watzstein, 1994).

\section{CONCLUSION}

The alternative carbon sources tested failed to promote growth of cell cultures of the three studied species. However, sorbitol showed its potencial to be used as a promoter of cell differentiation in suspension cultures of $C$. zedoaria, $B$. forficata and $P$. vulgaris. The rate of cell differentiation in sucrose and sorbitol and whether or not the other carbon sources may induce cell differentiation need to be evaluated in optimized growth medium composition and auxins concentration.

\section{ACKNOWLEDGMENT}

To the financial support by the Fundação de Amparo à Pesquisa do Estado de São Paulo (FAPESP).

\section{REFERENCES}

BELLETTRE, A.; COUILLEROT, J.P.; VASSEUR, J. Effects of glycerol on somatic embryogenesis in Cichorium leaves. Plant Cell Reports, v.19, p.26-31, 1999.

BRADFORD, M.M. A rapid and sensitive method for the quantitation of microgram quantities of protein utilizing the principle of protein-dye binding. Analytical Biochemistry, v.72, p.248-254, 1976.

BURNS, J.A.; WATZSTEIN, H.Y. Storage reserves in pecan somatic embryos derived from suspension cultures. Plant Science, v.102, p.213-219, 1994.

CABASSON, C.; OLLITRAULT, P.; CÔTE, F.X.; MICHAUXFERRIÈRE, N.; DAMBIER, D.; DALNIC, R.; TEISSON, C. Characteristics of Citrus cell culture during undifferentiated growth on sucrose and somatic embryogenesis on galactose. Physiologia Plantarum, v.93, p.464-470, 1995.

CARVALHO, R.N. Cultivo in vitro de Bauhinia forficata Link. Piracicaba, 1998. 51p. Dissertação (Mestrado) - Escola Superior de Agricultura "Luiz de Queiroz", Universidade de São Paulo.
EL MAATAOUI, M.; ESPAGNAC, H.; JABER, B.; ALONSOLOPEZ, A. Regulation of in vitro callogenesis and organogenesis from Albizzia root explants by carbohydrate source modifications. Journal of Plant Physiology, v.152, p.494-501, 1998.

FRICK, H. Heterotrophy in the Lemnaceae. Journal of Plant Physiology, v.144, p.189-193, 1994.

FRICK, H.; MORLEY, K. Metabolism of lactose by Lemna minor L. (Duckweed) callus. Process Biochemistry, v.30, p.57-62, 1995.

HARADA, H.; MURAI, Y. Micropropagation of Prunus mume. Plant Cell, Tissue and Organ Culture, v.46, p.265-267, 1996

JAIN, R.K.; DAVEY, M.R.; COCKING E.C.; WU, R. Carbohydrate and osmotic requirements for high-frequency plant regeneration from protoplast-derived colonies of indica and japonica rice varieties. Journal of Experimental Botany, v.48, p.751-758, 1997.

JONES, A.; VELIKY, I.A. Growth of plant cell suspension cultures on glycerol as a sole source of carbon and energy. Canadian Journal of Botany, v.58, p.648-657, 1980.

KARHU, S.T. Sugar use in relation to shoot induction by sorbitol and cytokinin in apple. Journal of the American Society for Horticultural Science, v.122, p.476-480, 1997.

LEIFERT, C.; MURPHY, K.P.; LUMSDEN, P.J. Mineral and carbohydrate nutrition of plant cell and tissue cultures. Critical Reviews in Plant Science, v.14, p.83-109, 1995.

LEMOS, E.E.P.; BLAKE, J. Micropropagation of juvenile and mature Annona muricata L. Journal of Horticultural Science, v.71, p.395-403, 1996.

LOESCHER, W.H. Physiology and metabolism of sugar alcohols in higher plants. Physiologia Plantarum, v.70, p.553-557, 1987.

MARINO, G.; BERTAZZA, G.; MAGNANINI, E.; ALTAN, A.D. Comparative effects of sorbitol and sucrose as main carbon energy sources in micropropagation of apricot. Plant Cell, Tissue and Organ Culture, v.34, p.235-244, 1993.

MURASHIGE, T.; SKOOG, F. A revised medium for rapid growth and bioassays with tobacco tissue cultures. Physiologia Plantarum, v.15, p.473-497, 1962.

OKAZAKI, K.; KOIZUMI, M.; NISHIO, T.; DORE, C. Callus formation and regeneration of some species of Lilium. Acta Horticulturae, v.392, p.97-106, 1995.

SAS INSTITUTE. SAS user's guide: Statistics. 6.ed. Cary: Statistical Analysis System Institute, 1996. 956p.

SMITH, C.J. Carbohydrate Chemistry. In: LEA, P.J.; LEEGOOD, R.C. Plant biochemistry and molecular biology. Chichester: John Wiley \& Sons, 1995. p.73-111.

SPIEGEL-ROY, P.; SAAD, S. Regeneration from salt tolerant callus in Citrus. Advances in Horticultural Science, v.11, p.3-9, 1997.

SWEDLUND, B.; LOCY, R.D. Sorbitol as the primary carbon source for the growth of embryogenic callus of maize. Plant Physiology, v.103, p.1339-1346, 1993.

TSUKAHARA, M.; HIROSAWA, T.; KISHINE, S. Efficient plant regeneration from cell suspension cultures of rice (Oryza sativa). Journal of Plant Physiology, v.149, p.157-162, 1996.

VU, J.C.V.; NIEDZ, R.P.; YELENOSKY, G. Glycerol stimulation of chlorophyll synthesis, embryogenesis and carboxylation and sucrose metabolism enzymes in nucellar callus of "Hamlin" sweet orange. Plant Cell, Tissue and Organ Culture, v.33, p.75-80, 1993.

ZIMMERMANN, M.H.; ZIEGLER, H. List of sugar alcohols in sieve-tube exudates. In: ZIMMERMANN, M.H.; MILBURN, J.A. (Ed.) Encyclopedia of plant physiology new series. Berlin: Springer-Verlag, 1975. p.480-503.

Received August 07, 2000 